Production Planning \& Control: The Management of Operations 2019;30(10-12):919-934.

\title{
Effect of Best Management Practices on the Performance and Productivity of Small Firms
}

\author{
Tahir M Nisar
}

Southampton Business School, University of Southampton, Southampton, SO17 1BJ, United Kingdom.

\section{t.m.nisar@soton.ac.uk}

Niraj Kumar

University of Liverpool Management School, Chatham Street, Liverpool, L69 7ZH, United Kingdom.

niraj.kumar.dr@gmail.com

Guru Prabhakar

Faculty of Business \& Law, University of West of England, Bristol BS16 1QY, United Kingdom.

Guru.Prabhakar@uwe.ac.uk

Published in

"Production Planning \& Control: The Management of Operations"

$30^{\text {th }}$ June 2019 
Production Planning \& Control: The Management of Operations 2019;30(10-12):919-934.

\title{
Effect of Best Management Practices on the Performance and Productivity of Small Firms
}

\begin{abstract}
Recent research on productivity finds that best management practices are a crucial but neglected element in explaining firm productivity. This stream of research also focuses on why a large number of firms may not implement best management practices despite their apparent benefits. In this paper, we examine the adoption of best management practices in small leveraged buyout (LBO) firms. Our choice of small LBO is motivated by the fact that these firms undergo extensive restructuring and therefore there is an opportunity to study the adoption process of best management practices. The findings show that buyout companies introduce best management practices (operations, monitoring, targets and incentives related practices) at different stages of their development, and more importantly, these practices evolve in response to changes in various firm-level characteristics. For example, companies emphasising cost leadership tend to follow targets and monitoring related practices while firms following a differentiation strategy are more likely to implement incentives and operations related management practices. Buyout sponsors' board representatives and new CEO also play a critical role in the adoption of these best management practices which are linked to superior firm performance, measured as growth in revenues, productivity and return on assets.
\end{abstract}

Keywords: Best management practices; Small Firms; Buyouts; Firm performance. 


\section{Introduction}

Firms use management practices to direct, support and motivate individuals to perform their specific organizational roles. Management practices thus handle a large amount of diverse information, mainly taking the form of rules, routines, documentation and formalized structures (Child and Mansfield, 1972; Bagnoli and Vedovato, 2014; Centobelli et al. 2017a;). In a recent flurry of research, it has been shown that "best" management practices improve firm productivity (Aboelmaged, 2014; Hanna and Jackson, 2015). For instance, Bloom and Van Reenen (2007) and Bloom et al. (2011) examined the role of product market competition, among other factors, in determining the degree to which best management practices are adopted by firms in the United States, Britain, Germany, and France. They argued that managerial practices positively contribute to firm-level productivity, and that these relationships are chiefly observed when firms face higher levels of product market competition. The study also showed a long tail of poorly managed firms, raising questions about why variations in the adoption of best management practices exist in the first place (Durst and Wilhelm, 2012; Inkinen, 2016; Massaro et al., 2016).

In subsequent literature, it was found that external interventions can bring large benefits to the firm that is subjected to a field experiment. Bandiera et al. (2011) explained, “... the fact that in so many cases firms have managed to increase profits appears at odds with the common assumption that firms are pressured by competitive forces to make at least near-competitive close-to-optimal choices (p.78)." They attribute the failure of firms to implement such practices to high opportunity costs that would be incurred in owners' time in exploring the expected benefits. These concerns also relate to the wider question of what motivate firms to adopt productivity-enhancing practices and technologies (Black and Lynch, 2001; Syverson, 2011). For example, after exploring the U.S. cement industry, Syverson (2004) found that a higher level of productivity is associated with tougher competition and firm-level competition arising from the fear of going bankrupt may also increase the managerial effort to perform.

In this study, we investigate how best management practices evolve in small-scale leveraged buyout (LBO) firms in response to various firm-level changes (Cyert and March, 1963; Nelson and Winter, 1982; Greiner, 1972). Apparently, Literature is currently very limited on understanding how small-scale firms adopt a variety of management practices as they grow with the passage of time (Durst and Wilhelm, 2012; Inkinen, 2016). Moreover, the significant contributions of small firms in nation's economy also make it important to explore the best management practices of small firms and to understand how these practices impact their performance. For example, as firms face new market challenges, demands on their control and 
coordination mechanisms also grow, resulting in an inability to cope effectively with increasing information needs (Williamson, 1971; Edvardsson and Durst, 2014; Durst et al. 2015). Firms may respond to these failures by engaging in the process of change, modification and revamping of their existing management practices, especially in instances such as when a major re-organization occurs. In this paper, we focus on leveraged buyout (LBO) firms because their practices are subject to change as the new owners of the firms will likely to have an overt interest in implementing various performance improvement measures over the medium to longterm period. This study investigates both the changes in the configuration of best management practices, as well as the motivations and drivers behind these changes. More specifically, we ask: whether buyout firms following low cost strategies implement target and monitoringrelated best management practices; whether buyout firms following differentiation strategies implement incentives and operations-related best management practices; and, finally, whether buyout firms implementing best management practices experience superior performance.

As evolutionary and adaptive theories predict, firms adopt workplace practices in response to an evolving need for minimizing information processing costs as their operations grow and expand (Nelson and Winter, 1982). Changes in the firm's internal and external environment may also induce the demand for specific practices (Cyert and March, 1963; Dosi and Marengo, 2007; Cerchione and Esposito, 2017; Centobelli et al., 2017b). In past, evolutionary and adaptive firm theories have been used in different contexts to explain firm practices such as innovation, industry structures, and networks and alliances (Osborn and Hagedoorn, 1997; Agarwal et al., 2002; Wright and Zammuto, 2012). For example, Strang and Still (2004) state that these two lines of argument are central to sociological treatments of organizational diffusion. The Carnegie School's analysis of decision-making treats organizations as boundedly rational adaptive agents engaged in problem-driven search (March and Simon 1958; Cyert and March 1963). However, institutional studies of organizational change argue that firms emulate more legitimate or successful others (DiMaggio and Powell 1983). Together, these ideas provide accounts of the intensity and direction of search. As mentioned, the specific context we use is that of small-scale LBO firms. LBO is a form of investor activism of public firms that have incurred agency costs beyond an optimal point (Kaplan, 1989; Jensen, 1989). LBO are also associated with organizational change and development, both in the way a buyout firm's strategic and organizational context changes and how these changes influence its management practices (Cumming et al., 2007; Cornelli and Karakas, 2008; Kaplan and Strömberg, 2009). For instance, most LBO vigorously implement a cost cutting strategy as soon as a new management team is put in place. This inward focus 
gradually shifts to an outward focus when buyout sponsors are nearer the exit from their investment, mirroring the need for a more diversified product market strategy ${ }^{1}$. Such an environment lends itself especially well to a study of how changes occur in the firm's management practices. Many new practices are adopted in the event of a breakdown in processes such as a failure to meet deadlines or quality problems. It is likely that buyout firms actively use best management practices to ameliorate organizational failures that characterize pre-buyout firms. By studying these evolutionary adoption processes, we thus advance the existing research on both best management practices and the way small-scale firms adopt these practices to meet the challenges of growth and competitiveness. The power of knowledge has come to be an important resource for organizations to develop expertise, solve problems, increase organizational learning, and initiate new situations for both the individual and the organization now and in the future (Durst and Wilhelm, 2012; Inkinen, 2016). The amplified velocity and dynamic nature of the new economy, partnered by substantial advances in technology has created an incentive for many organizations to reconcile and utilize their knowledge in order to generate value over a sustained period of time. The effective utilization of a firm's intangible assets have also functioned as catalyst for creating competitive advantage over other organizations operating in the market.

This study contributes to the growing literature on best management practices in three important aspects. First, the study investigates the evolution of best management practices over time in order to fully understand their adoption process. Assuming management practices are reflected in the multitude of activities that a firm engages in, we show how management practices evolve as small firms restructure their production or service-related activities. According to the evolutionary firm perspective, firm routines develop over time (Nelson and Winter, 1982) and, therefore, it is unlikely that the trajectory of 'best management practice' adoption will be uniform. There will be significant changes in how best management practices are adopted as various firm-related behavioural changes come into play at various points in time (Cyert and March, 1963; Dosi and Marengo, 2007). This is especially the case when LBO firms are engaged in problem-driven search for better organizational and management systems. Prior studies not only neglected the issue of adoption process, but also failed to offer convincing explanations of why some firms do not implement best management practices and behave in a suboptimal fashion. As organizations must consider a wide variety of technical and

\footnotetext{
${ }^{1}$ Leveraged buyouts are normally undertaken by private equity firms who raise specialist funds for the purpose. However, since private equity firms also raise funds for dealing with operations such as distressed debt, the common industry practice to distinguish between these activities is to call buyout funds as buyout sponsors.
} 
human issues when choosing the 'right' mix of a knowledge management system in order to lever knowledge effectively, the firm's energy, organizational activity, and investment can often lead to ineffective knowledge management initiatives. Second, whereas in the studies cited above, 'competition' is the only determining factor considered, in this study we additionally examine the role of factors such as firm strategies, debt and board composition. In this regard, we build our specific hypotheses based on evolutionary organizational learning theories that emphasize the critical role of firm-level changes, past and present, in the development of specific firm routines, capabilities or workplace practices (Ethiraj and Levinthal, 2004).

Finally, the present research adopts the methodological innovation of investigating management practices across firms. Extant management research mainly focuses on management practices within firms (Huselid, 1995). This approach is useful to the extent that it allows an investigator to research interactions among different sets of management practices. However, it does not explicate how different management practices are implemented across firms and, therefore, it may not be possible to derive general conclusions about the contribution of management practices to productivity. We also investigate the impact of best management practices on buyout firm performance. These questions are addressed by analyzing both qualitative and quantitative data related to the choice of best management practices by a sample of buyout firms. We can therefore establish the links between the various motivations and drivers of 'best management practice' adoption, and their impacts on productivity.

The paper is organized as follows. Section 2 critically reviews the literature and develops the key hypotheses to be tested in this study. Section 3 discusses the research methodology adopted in this study and section 4 presents the analysis and findings. At the end, section 5 discusses the findings and concludes the paper.

\section{Background research and hypotheses}

This section first discusses and reviews the extant literature in three different areas, including leveraged buyouts, evolutionary perspective and specific management practice related literature, such as knowledge management and supply chain management. Based on this analysis, we then develop our specific hypotheses.

\subsection{Managerial Capital: An Evolutionary Perspective}


Best management practices imply that bad practices can exist along with good practices. A firm may begin with good practices but over time some of these practices may degenerate into bad practices. If the firm is able to select more good practices than bad practices, then it can benefit from a higher level of productivity. The reverse is also true, however, and it is likely that the firm will not fully enjoy the fruits of productivity. This suggests that when we conceptualize best management practices, we must also contemplate the possibility that a firm is endowed with good practices as well as bad practices and that there is an evolutionary process involved in selecting best management practices. In other words, it is important to understand the adoption process of best management practices. Bouvier and Nisar (2012) describe a firm's current stock of management practices as 'managerial capital.' It is thus possible to show that a firm may have a higher level of managerial capital compared to other firms or vice versa. These ideas are best supported by the evolutionary and behavioral frameworks of Nelson and Winter (1982) and Cyert and March (1963).

The evolutionary perspective postulates that institutions like firms can be better understood by analyzing routines as the building block of productive organizations (Nelson and Winter, 1982; Greiner, 1972). Nelson and Winter (1982) recognized the limitations of the individuals to process all relevant information in the workplace and this limitation underpins their theory of 'routines'. As Nelson and Winter (1982: 35) explained that "Man's rationality is 'bounded': real-life decision problems are too complex to comprehend and therefore firms cannot maximize over the set of all conceivable alternatives. Relatively simple decision rules and procedures (i.e. routines) are used to guide action, because of the bounded rationality problem these rules and procedures cannot be too complicated." The motivation for explicating routines to understand the nature of the firm draws a great deal on the processes by which the firm becomes the repository of knowledge, contingent on the firm's past history. There can also be a number of other factors arising from changes in the firm's internal and external environment such as changes in competition that influence the development of these processes (Cyert and March, 1963; Dosi and Marengo, 2007). The knowledge capability pertinent to the firm's operations is accomplished over a period of time, as particular ways of doing things become standard practices to be followed by individual employees (Abell et al., 2008; Dosi and Marengo, 2007).

Building on these ideas, extant management literature has generally focused on understanding those attributes of management practices that minimize information processing costs in different organizational contexts - a process necessary for understanding the evolution of best management practices (Eisenhardt, 1985; Herremans, et al. 2011). This study aims to 
identify the nature and scope of different management practices in adaptive environments. For example, when it is difficult to measure performance outcomes or when they are less reliable as indicators of a manager's 'true' performance, best management practices may facilitate the decision-making process by helping managers to update their beliefs about the choices they make and the consequence they receive (Chandler, 1962; Cyert and March 1963).

In recent literature, attempts have been made to go a step further and classify best management practices in terms of a specific set of categories. Bloom and Van Reenen (2007) examined the degree to which best management practices contribute to firm-level productivity. They group management practices into four areas: operations; these are three practices that are related to the introduction of lean manufacturing techniques, the documentation of processes improvements, and the rationale behind introductions of improvements; monitoring; these are five practices that are related to the tracking of performance of individuals, reviewing performance (e.g., through regular appraisals and job plans), and consequence management (e.g., making sure that plans are kept and appropriate sanctions and rewards are in place); targets; these are five practices that are related to the type of targets (whether goals are simply financial or operational or more holistic), the realism of the targets (stretching, unrealistic, or nonbinding), the transparency of targets (simple or complex), and the range and interconnection of targets (e.g., whether they are given consistently throughout the organization), and incentives; these are five practices that are related to promotion criteria (e.g., purely tenure-based or including an element linked to individual performance), pay and bonuses, and fixing or firing bad performers. Bloom and Van Reenen (2007) found support for the hypotheses that all the above-mentioned practices are positively related to firm productivity. They also found a significant number of poorly managed firms. Bloom et al. (2011) suggested that firms may not adopt best management practices due to a number of factors. For example, in some circumstances it may be costly to introduce new management practices. For the firm implementing new management practices overall impact may be negligible as profits remain more or less at the same level even if productivity rises due to the improved practice of company management. In some other firms, the separation of control from ownership may result in managerial entrenchment, whereby managers stick to those practices that require less effort on their part. They may not adopt optimum practices because of the difficulty in providing appropriate incentives for doing so. Bloom and Van Reenen (2010) also propose the idea of differential costs and/or benefits that exist when implementing best management practices. In addition, learning effects and slow adjustments may mean that best management practices may not be fully adopted at a point in time, even if the benefits of such 
practices are obvious. Other factors that may impinge upon the adoption process include capital markets, labor market regulations, trade unions and corporate governance (Bertrand and Schoar, 2003; Bloom et al., 2011).

In terms of the management areas where adaptive processes occur more recurrently and best management practices as defined by Bloom and Van Reenen (2007), a typology of the interrelationships between both these areas of interest can be developed (as provided in Table 1). Next, the question of the firm-related specific factors that might impinge upon the adoption of best management practices would be addressed. As discussed above, we focus on LBO type firms in order to delineate the determinants of the adoption of best management practices. This will also allow us to formulate more specific research hypotheses for our study.

\section{$<$ Insert Table 1 about here >}

\subsection{LBO firms and Best Management Practices}

Buyouts are structured to provide significant equity incentives to the entrepreneurs, together with substantial external funding and active monitoring by investors (Jensen, 1993; Wright et al., 1994). Buyouts occur with a varying degree of debt-equity ratios but a major part of leveraged buyouts is the use of substantial debt for controlling the company. Early research on LBO viewed the buyout of public firms as a means of reducing significant agency costs in the form of free cash flows (Jensen, 1989; Fox and Marcus, 1992; Halpern et al., 1999). As managers' and shareholders' interests are not fully aligned, managers sit on huge piles of free cash flow and use them as a protection mechanism against downside risk. An LBO curtails this inefficient use of firm resources and diverts free cash flows toward debt repayment. LBO also represent higher share of insider equity that creates incentives for value maximization through its effect on the alignment of interests between shareholders and managers. As LBOs aim to create an alignment of interests between owners and managers, they are likely to implement best management practices as they have an innate ability to support efficient decision making, better resource allocation and utilization and improved monitoring and control.

\subsection{Firm Strategy and Best Management Practices}

LBO firms provide a context in which the presumed association between strategy and best management practices can be fully investigated. Economics studies researching the adoption of best management practices are limited to the factor of competition as a key relevant determinant (Bloom and Van Reenen, 2007; Bloom et al. 2011). However, a stream of 
management research that investigates different types of management systems and practices emphasize the link between company management practices and strategy (Centobelli et al. 2017a \& b; Cerchione and Esposito, 2017). For example, Hill and Hoskisson (1987) and Langfield-Smith (1997) investigated the link between strategy and management control systems and focus on the relationship between general strategic context of a firm and how it influences its control structures. Govindarajan and Fisher (1990) and Snell (1992) examined aspects of a firm's operational strategic contexts such as business-unit level product-market variation, work flow integration and organizational size and their effects on firm management. Overall, these and other studies draw their inspiration from contingency theories of management, according to which management practices are implemented in response to specific industry factors. For example, supply chain management practices require particular industry focus (Kotzab et al., 2015; Zhang et al., 2017).

LBOs in the 1980s and 1990s were mainly aimed at providing efficiency incentives as most buyouts took place in mature and stagnating businesses (Jensen, 1989; Kaplan, 1989; Phan and Hill, 1995). While still maintaining this interest in mature industries, recent waves of LBO are more likely to be found in growth and emerging industries (Kaplan, 2007; Cumming et al., 2007). As a result, it is sometimes argued that LBO act as a vehicle for entrepreneurial initiative (Bruining and Wright, 2002) and promote technological innovation and growth (Kaplan and Strömberg, 2009). Regardless of the motive for taking a company private, LBO create a juncture at which there is an opportunity to reconsider the strategy of a firm and streamline its management systems. Buyouts may initially be concerned with enhancing efficiency and protecting the firm against downside risks but the subsequent changes can be far-reaching and may encompass all aspects of company management (Bruining and Wright, 2002). From improvements in the quality of information to introducing equity-based incentives through to spelling out clear basis for performance measurement can all be part of this change program.

Traditionally, buyout sponsors are concerned with streamlining the operations of their portfolio companies to meet performance challenges (Kaplan, 1989, 1991). To bring management and production systems into alignment with efficient cost structures, the sponsors may take steps such as (1) employing people with high levels of experience and practicing all possible economies of scale; (2) producing a standard, undifferentiated product; and (3) giving employees targeted incentives. These strategies are underpinned by a standardized production system, requiring the performance of a routinized set of tasks. In the lexicon of organization theory, when production can be defined in terms of routines and repetitive procedures, the 
knowledge of ends and means is high, implying high task programmability (Siders et al. 2001; Woolley, 2009). Targets-based best management practices may then be implemented to secure buyout company manager compliance (Baron et al., 1996). However, when product-market variations are greater, with a high degree of breadth and change in the firm's products or markets (Snow and Hrebiniak, 1980; Woolley, 2009), there may be an increasing demand on the information-processing capabilities of the firm (Egeihoff, 1982; Beersma, et. al. 2003;). There will then be a need for monitoring the structuring of firm's operations. A buyout is more likely to experience these changes when the sponsors seek to prepare their companies for sale. An investment will exit on favorable terms if the company's revenue stream is stable and based on better quality products.

Given the focus on both cost reduction and revenue growth in a buyout, Porter's (1980) strategy framework can be used to construct relevant strategy parameters (Sandino, 2007). Porter (1980) views strategy in terms of a trade-off between cost leadership and product differentiation. However, empirical research has shown that these generic strategies may be linked in a variety of ways (Hill, 1988; Jones and Butler, 1988; Murray, 1988; Bagnoli and Vedovato, 2014; Centobelli et al. 2017a), and, therefore, they may not be mutually exclusive. Strategy trade-offs are generally about identifying company goals on a continuum between companies following a 'cost leader' or 'defender' strategy and those following a 'growthoriented' or 'differentiation' strategy (Miles and Snow, 1978). In the present context, characteristics of a company with a low-cost product strategy match those of a buyout firm's traditional restructuring program while a product differentiation strategy is linked to a buyout sponsor's need to make its investments more attractive in terms of its differential offerings. As evolutionary and adaptive theories of organization would suggest (Cyert and March 1963), firms following a strategy of cost leadership are more likely to use best management practices related to operating targets and monitoring, while firms following differentiation strategies may adopt structures and processes that target individual responsiveness to changes in the environment. These are more likely to be accomplished by best management practices related to operations and incentives. One can argue that these practices meet the evolving demands of information and knowledge management as firms grow (Cerchione and Esposito, 2017; Centobelli et al. 2017b). Knowledge management and intellectual resources are increasingly important factors in the outstanding achievement of organizational objectives (Durst and Wilhelm, 2012; Kotzab et al., 2015; Inkinen, 2016; Zhang et al., 2017). Higher levels of efficiency mean that knowledge becomes an important source of competitive advantage (Centobelli et al. 2017b; Cerchione and Esposito, 2017). This requires organizations to 
understand the relationships between physical, financial, and intellectual capital to increase their market value and to achieve corporate sustainability. Organizations that operate in innovation and technology intensive markets place greater emphasis on facilitating and maintaining knowledge-sharing cultures that are integrated and supported by a company's employees, its systems and processes, and technology in order to remain competitive (Durst and Wilhelm, 2012; Inkinen, 2016). The literature appears to agree that trust and social identification are the most widely recognized reasons causing positive effects for knowledge sharing.

The above discussion of the role of best management practices in leveraged buyouts leads us to formulate the following specific hypotheses:

Hypothesis 1: Buyout firms following low cost strategies will implement target and monitoring-related best management practices.

Hypothesis 2: Buyout firms following differentiation strategies will implement incentives and operations-related best management practices.

\subsection{Best Management Practices and Performance}

Firm's adoption of best management practices ensures that individuals' efforts are fully directed toward achieving targeted levels of performance (Bloom and Van Reenen, 2007). Similarly, buyout firms implement various sets of best management practices, as identified in the previous section, that helps achieve better control and monitoring. One can show that best management practices encompass various components of knowledge management that enhance the ability of the organizations to perform better and more efficiently and effectively (Bagnoli and Vedovato, 2014; Centobelli et al. 2017a). A shared understanding of organizational practices will likely engender greater commitment and trust among the group workers. It would help provide access to useful information, judgements, and views leading to solving difficult problems (Cerchione and Esposito, 2017; Centobelli et al. 2017b). Buyout sponsors have a financial claim on the company and as such they are interested in the financial success of the enterprise. Hellmann and Puri (2002) argued that the presence of professional funding in the company's financial structure explains significant variation in the level of professional management in venture-backed firms. Buyout sponsors are also likely to encourage their portfolio companies to restructure their operations so as to achieve improved performance. Such a strategy will lead to their exit within a specified timeframe, thus enabling 
the sponsors to close their funds and return capital to their investors as per contractual terms (Kaplan, 1991)2. We therefore examine the following hypothesis:

Hypothesis 3: Buyout firms implementing best management practices will experience superior performance.

\section{Research design}

In this study, the evolution of best management practices (BMP) in 208 European-based buyout companies is examined (see Table 2). The research methodology involves first constructing a sample of buyouts for this study. We then develop a detailed testing model, including definitions of independent variables and dependent variables. At the time of sampling, companies (i) had a minimum of 50 employees, (2) were more than ten years old, and (3) 60 percent or more debt was used in the buyout transaction. The research methodology adopted in this study involves selecting a dataset based on a number of criteria stated. Once admitted into the sample, we go back to the genesis of these companies and track the build up of BMP from the buyout date to the time of study. The buyout date was obtained from the S\&P's Leveraged Commentary \& Data (LCD). Because information about company BMP is not readily available from public sources, it was necessary to develop our own research instruments for this study's purpose. As a first step, the profile of each company was built by collecting information from company web pages and press releases from EBSCO and Lexis-Nexis. From these sources, we had enough information about company products, key personnel and company history of mergers and acquisitions. These datasets also give reliable information about each European country's institutional and economic environment, thus allowing the selection of buyouts on comparable institutional / economic performance indicators.

As discussed above, LBO firms provide debt discipline to curtail agency costs. However, debt leverage used by private equity sponsors has steadily declined after the heady days of buyouts of the 1980s (Jin and Wang, 2002; Kaplan, 2007). ${ }^{3}$ The interviewees suggested that there had been an upward movement again in leveraged finance for buyout deals post-2000 when the

\footnotetext{
${ }^{2}$ PE sponsors make their investments via LBO funds that have a limited life span of 10-12 years.

${ }^{3}$ In the 1980s and 1990s, apart from a few private equity firms, buyout activity was mostly undertaken by European venture capital firms. It was therefore likely that the amount of leverage used in buyout activity was less then the one used in U.S-based firms. However, post-2000 a large number of European-based firms have raised private equity funds that solely target leveraged-buyout activity. US-based private equity firms have also established their offices in several European countries to directly participate in the local buyout market. These trends have helped converge buyout practices in both sets of markets.
} 
sponsors faced improved financial conditions; but, for the sake of consistency, we selected buyout firms with a minimum debt component of 60 percent $^{4}$.

\section{$<$ Insert Table 2 about here $>$}

Exploratory interviews with fourteen buyout professionals was the next step to develop an initial understanding of the types of best management practices commonly implemented in buyout firms. We selected buyout professionals based on their industry reputation; for example, if they are members of the venture capital and private equity association. Subsequently, using questionnaires and semi-structured interviews the information about key research variables were obtained, including information on firm strategy, board structure, and employment of professional staff. Moreover, an account of the firm's best management practices were also collected with details about which practices were introduced at various stages of the buyout and if they were still in use at the time of the interview. In most cases, the questionnaire was completed in face-to-face interviews with either the CEO or the human resource (HR) manager. Interviews with each company's chief financial officer (CFO) and the marketing/product development manager were also conducted. The semi-structured interviews with each of these four managers generally lasted about an hour, and were used to obtain information about the interviewee's experience with best management practices, from initial design through implementation. There are certain limitations of the interview method such as respondents' bias regarding 'acceptable practices' or they may be subject to recall bias (Seidman, 1998). To mitigate this limitation, various dimensions of a particular variable were included, and contrasted their responses to other available information. We obtained financial information from Orbis, which is a rich source of information about both public and private companies. The data collected were sufficient to gather a large enough variation to examine the hypotheses developed in this study.

The research methodology then entails using Bloom and Van Reenen's (2007) measures of best management practices. An example of scoring grid for each set of management practices is provided in appendix 1 . The mean score for all items included in a scale is used to create value for each one of these scales. To confirm that the variables were distributed normally and the actual response patterns were in accordance with expectations, different statistical methods including normal probability plots, histograms and factor analysis

\footnotetext{
${ }^{4}$ Private equity is also associated with 'flipping' their buyout companies in a short space of time. In our empirical research, we took care to include only those companies where the investor hold period is more than the industry average (Kaplan, 1991).
} 
are employed. LBO performance is measured by employing three measures: revenue growth, productivity and return on assets (ROA). The choice of the productivity measure was primarily because, compared to changes in profitability, changes in productivity are likely to show up sooner. Earnings before interest, taxes, depreciation and amortization (EBITDA) over total labor costs is used to measure labor productivity. The use of total labor costs as denominator allows to account for variations among firms' salary structures. Revenue growth and the change in return on assets (ROA), defined as EBITDA/total assets are other performance measures.

\subsection{Measurement of Variables}

Both economics and management literatures stress on several important reasons for the adoption of best management practices, including agency cost, cost-benefit trajectory of decision support systems, strategy and size. In the following section, we develop specific variables that are used to examine the extent of variation in the types of best management practices adopted by buyout firms. As discussed above, our specific variables are drawn from the three strands of the literature that form the basis of our hypotheses. These include buyout literature, best management practice literature, including knowledge management and supply chain and evolutionary approaches. In defining the variables, we also briefly refer to their motivations; in particular, how best management practices contribute to firm-level productivity.

Best management practices: Bloom and Van Reenen's (2007) measures of best management practices, including operations, monitoring, targets and incentives related practices is adopted in this study. By using multiple respondents, interrater reliability is ensured (measure reliability was $0.66(\mathrm{p}<0.001)$ ). To confirm control measure dimensionality empirically, a principal components factor analysis with varimax rotation is conducted to assess convergence within and divergence between scales. Based on this anlayis, four stable factors representing operations, monitoring, targets and incentives are derived, each having an eigenvalue greater than 1.0 and together accounting for 52 percent of variance in the data.

Strategy: Extant research identifies business strategy as a relevant key factor in explaining cross-sectional variation in the design and implementation of different sets of management practices (Hill, 1988; Langfield-Smith, 1997). Chandler (1962) observed that the strategic posture of a firm affects the absorption level of its administrative information. In addition, knowledge management and intellectual resources have become increasingly important factors in the special achievement of organizational objectives (Durst and Wilhelm, 2012; Inkinen, 2016); higher levels of efficiency mean that knowledge becomes an important 
source of competitive advantage (Cerchione and Esposito, 2017; Centobelli et al. 2017b). To capture the impact of firm strategy on best management practice adoption, two variables; cost leadership and differentiation are used. Following Hill (1988) and Sandino (2007), we define COSTLEADERSHIP and DIFFERENTIATION as follows ${ }^{5}$ :

COSTLEADERSHIP is a composite measure that proxies for the firm's cost leadership strategy. It is a principal component measure that captures 73 percent of the variation in two questions: (1) the extent to which the firm places an emphasis on lower prices as a way to maintain its market position, and (2) the extent to which the firm directs its operations toward controlling cost and offering lower priced goods. Using a Likert scale, these questions place higher values on strategies emphasizing cost efficiency targets - 7 - and lower values for firms indifferent to cost restructuring -1 .

DIFFERENTIATION is a composite measure that proxies for the firm's differentiation strategy. It is a principal component measure that captures 66 percent of the variation in two questions: (1) the extent to which the firm offers unique products as a way of extending its market reach, and (2) the extent to which the firm emphasizes knowledge growth and capability improvement in its revenue-generating operations. As discussed, organizations that operate in innovation and technology intensive markets place greater emphasis on facilitating and maintaining knowledge management systems and knowledge-sharing cultures that are integrated and supported by a company's employees, its systems and processes (Durst and Wilhelm, 2012; Inkinen, 2016). Using a Likert scale, these questions place higher values on strategies emphasizing high product differentiation - 7 - and lower values for firms indifferent to product improvements -1 .

Board: As a buyout aims to improve company performance by aligning owner-manager interests, changes in corporate management will be necessary to strengthen the firm's traditional monitoring function. Due to agency problems, there are severe monitoring inadequacies in boards of public firms that cause buyout sponsors to replace passive outsiders with active investors (Jensen, 1989). Buyout sponsors may sit on LBO firm boards, and since these sponsors often hold majority equity shares in LBO, they are likely to exercise considerable influence over company managers (Kaplan, 1991; Holthausen and Larcker, 1996). Evidence shows that LBO boards are structured to yield strong returns to investors and

\footnotetext{
${ }^{5}$ We have earlier noted the limitations of adopting this approach as empirical research suggests that such generic strategies may be linked in a variety of ways (Hill, 1988; Jones \& Butler, 1988; Murray, 1988), and, therefore, they may not be mutually exclusive. Similar to Sandino (2007) and others, we have adopted this approach in order to simplify our analysis.
} 
thus they represent "value-maximizing" boards (Cornelli and Karakas, 2008; Gertner and Kaplan, 1996). To measure the impact of investor involvement in 'best management practice' adoption, we examine whether buyout investors are part of the company's board of directors (when board does not exist, we ask if the buyout sponsor has appointed a specialist person to deal with the portfolio company). Extant literature on best management practices also suggests that in some situations external interventions may be necessary to bring about changes in the firm's management practices (Bloom et al., 2011). Board membership (BOARD) is a dummy variable updated yearly that takes the value of one if the buyout company has the sponsor's board member and zero otherwise. A measure of debt is also used to examine its impact on the adoption of best management practices in a buyout. Debt (DEBT) is the proportion of debt used in the LBO transaction.

\subsection{Control variables}

The research methodology also includes several control variables that are likely to affect the assumed relationship between best management practices and firm-level productivity. A number of control variables including buyout managers, competition, size and subsidiary based on the literature's discussion of various relevant factors is used that likely affect LBO transactions and their performance impacts. For example, Gabarro (1987) emphasizes the role of consultants and chief financial officers in change organizations.

Buyout managers: The adoption of best management practices will need to consider the question of costs and benefits of adding an additional layer of management practice to support decision-making. It can be argued that companies with more complex operations will adopt management practices that have a more favourable cost-benefit relationship (Simons, 1994) - it is time-consuming and costly to install and operate best management practices. These costs may be related to both the direct, short-term expenditure incurred in developing firmrelated best management practices, but also the indirect, long-term costs associated with unsuitable management practices. Given these considerations, one factor that is likely to influence the adoption/modification decision is the recruitment of professionals in areas directly linked to firm operations.

When buyout sponsors acquire a new business, they normally appoint top management team from outside the firm. It gives company management a break from the past but also a mandate to build up the scale of the enterprise that had been underperforming. Buyout companies are also driven by the specific management objective of turning around the business, which means that they are under significant pressure to improve performance. Gabarro (1987) 
finds in his field research of change organizations that new managers follow a dual strategy of (1) hiring consultants to design and implement new diagnostic control systems, and (2) recruiting a new chief financial officer to oversee the monitoring of critical performance variables. Similar effects are likely to be observed in buyout firms, and therefore, the impacts of new CEO, CFO, HR Manager and Marketing/Business Development Manager on the adoption of best management practices is evaluated. It is likely that these managers, having a functional background, are motivated to execute operational changes that reflect their own professional outlook, including the adoption of best management practices.

New CEO (CEO) is a dummy variable updated every year that takes the value of one if a new CEO has replaced the incumbent CEO, and zero otherwise. The presence of a full-time CFO is a time-varying variable that takes the value of one for those years in which the company had a full-time finance manager, and zero otherwise. Likewise, a full-time HR Manager (HR MANAGER) is a time-varying variable that takes the value of one for those years in which the company had a full-time HR manager, and zero otherwise. A similar variable for Marketing / Business Development Manager is also used. A full-time Marketing / Business Development Manager (BD MANAGER) is a time-varying variable that takes the value of one for those years in which the company had a full-time marketing manager, and zero otherwise. The information about the date in which a particular officer was hired was gathered from the $\mathrm{CEO} / \mathrm{HR}$ Manager questionnaire. This information was triangulated during the interview when the interviewee was asked to describe the relevant functional history of the company.

Competition: Economics literature on best management practices examines competitive environment as a key determining factor of 'best management practice' adoption. In this research, we also use a similar variable to capture the competitive positioning of the firms investigated. We asked our respondents to tell us about the number of direct competitors they faced in their particular markets (Minimum 1; Maximum 7).

Size: Informal contact among employees is the basis on which control and coordination occur in relatively small organizational environments. These settings are mostly related to the early developmental stages of a company, initiation of a new project or small-scale enterprises. With the number of employees increasing, however, it becomes necessary to develop a more formalized system of operations that anchors informal contact and communication around a set of fully written down and prescribed systems of governance. Controlling and coordinating large number of personal interactions inevitably increase the cost of governance (Lorsch and Morse, 1974). As personal interactions increase disproportionately, the ability of the system to cope well is also at risk. Thompson (1967) thus argues that with size the efficiency of an informal 
control approach rapidly decreases. We measure firm size (SIZE) as the natural logarithm of the number of employees working at the end of each year (The logarithmic transformation was used to reduce positive skew.)

It is expected that subsidiary firms, who often are targets of public to private LBO transactions, will use best management practices more intensely, given their experience of such systems. SUBSIDIARY is a dummy variable that indicates whether the LBO was subsidiary of a public firm (1) or not (0). The study also controls for industry. This variable may capture some of the differences across firms in terms of their external or product market environments (Hambrick, 1983). If the arguments that explain variation among BMP in well-established firms are relevant to change environments such as a buyout, then controlling for industrial sectors may enhance the power of the research design. For example, firms with more structured operations like product assembly may adopt output controls sooner because assembly tasks are more amenable to explicit coding compared to less structured operations like product development. Five industries are coded using dummy variables: manufacturing, trade, telecommunications, health and education, and IT industry. To study the impact of BMP on company performance, we use revenue growth, productivity and ROA, as defined above. We employ the productivity measure because, compared to changes in profitability, changes in productivity are likely to show up sooner. Similarly, the use of total labor costs in the performance measure of EBITDA allow us to account for variations among firms' salary structures. Our other performance measures include revenue growth and the change in return on assets (ROA), defined as EBITDA/total assets. These are more commonly use performance measures.

\section{Findings}

The percentage take up of each of the four best management practice systems by the end of Year 1 through Year 5 is reported in Figure 1(a). It plots the percentage of companies in the sample that report having adopted a system at the end of each year since buyout. One can glean several patterns from this information as the rate of adoption varies sizably across the sample. Monitoring and Targets emerge as the most widely adopted systems in Year 1 and Year 2 across the sample of firms. Operations and Incentives are not given that much weight in these first two years as the adoption of these systems is much slower than the Monitoring and Targets systems. This trend changes in Year 4 and 5 however with the increasing adoption of Operations and Incentives. Figure 1(b) plots the evolution of best management practice systems by headcount: (i) less than 75 employees; (ii) between 75 and 150; (iii) between 150 and 250; 
(iv) between 250 and 500; and (v) more than 500 employees. There is initially a rapid build-up of the best management practice systems until the size reaches 150 employees, and then again between sizes 250 and 500. Companies in these size categories introduce an assortment of new practice systems (or significantly revise them), alternating an emphasis first on Targets and then on Incentives. Both Figure 1 (a) and (b) provide important key information about the percentage take up of each of the four best management practice systems over time and the evolution of best management practice systems by headcount, respectively. In Figure 1(a) and 1(b), series 1 depicts Operations; series 2 depicts Monitoring; series 3 depicts Targets; series 4 depicts Incentives.

\section{$<$ Insert Figure 1 about here $>$}

The sample of companies contains 27 management buyouts (MBO). A management buyout involves members of the incumbent management team acquiring control of the company with a significant equity stake (Robbie and Wright, 1996). As such, there is greater incentive for the MBO managers to achieve performance targets as owner managers are likely to draw on control mechanisms extensively to ensure implementation of new or revised growth targets. However, this prediction does not bear out in the data collected. Figure 2 presents information for management buyouts (Figure 2a) and non-management buyouts (Figure 2b). The implementation of best management practices in both sets of sampled firms does not vary significantly. In Figure 2(a) and 2(b), series 1 depicts Operations; series 2 depicts Monitoring; series 3 depicts Targets; series 4 depicts Incentives.

$<$ Insert Figure 2 about here $>$

\subsection{Descriptive Statistics}

Descriptive statistics are provided in Table 3. Except size, all other variables increase over time. In the first two years, size decreases; however, this trend changes in the following three years, a pattern conforming to buyout company strategies. To cut costs, buyouts drastically slash a number of company operations, reducing their labor requirements. At later stages, when buyout sponsors start looking toward their exit and thrust the firms into exploring new growth opportunities they start re-employing labor and, as a result, their size also begins to increase. Firms with a buyout sponsor's representative on the board grow over time. Also those firms 
grow where incumbent CEOs have been replaced. As the timeline of best management practice adoption suggests, most of the individual practices introduced early are related to targets, while practices about incentives are introduced later.

\section{$<$ Insert Table 3 about here $>$}

Finally, Table 4 presents the correlation of the company observations in a selected number of categories.

$$
<\text { Insert Table } 4 \text { about here }>
$$

\subsection{Adoption of Best Management Practices}

The adoption of best management practices is measured in terms of the time it takes to introduce a specific set of best management practices. The time taken into account is the period from the company's buyout to the date of adoption of the practice and count the number of practices adopted per company in total and within each of practice set at the end of each year. Because the data is of discrete in nature, we use the Poisson regression model (Greene, 2000) to estimate the probability of observing a certain number of management practices adopted at a point in time. It is defined as follows:

$\operatorname{Pr}\left(Y_{i}=y\right)=\frac{e^{-\sum_{j} \beta_{j}^{*} x_{j}} *\left(\sum_{j} \beta_{j} * x_{j}\right)^{y}}{y !}$,

where $\mathrm{y}=0,1,2,3, \ldots$ is the number of practices adopted, $\mathrm{x}_{j}$ are the independent variables, and $\beta_{j}$ are the coefficients for the independent variables. The various independent variables include best management practices and the study's control variables. A coefficient on an independent variable greater (less) than 1 indicates that the explanatory variable increases (decreases) the probability of control system adoption. All variables are updated every year. The Poisson regression also controls for potential autocorrelation of error terms for observations from the same firm. We expect that company strategy, competition and agency costs, as proxied by a buyout sponsor's board membership, will be associated with a large number of practices adopted. Similar associations are expected for the perceived benefits and costs of introducing best management practices, as proxied by the appointment of professional staff and a new CEO ; company size, as proxied by employee headcount and whether the LBO was a subsidiary. 
Table 5 presents the results in the form of incidence rate ratios $\left(\mathrm{e}^{\beta}\right)$. As expected, the strongest results are about a buyout firm's need for developing relevant targets and monitoring practices. In the event of a takeover, the buyout firm board is usually restructured to reflect the interests of new investor owners. In our results, board member has a significant positive impact at the overall best management practices $(B M P)$ level, as well as at the levels of operations, monitoring, targets and incentives. Board members are likely to play a key role in focusing management attention toward specific restructuring goals, an important part of which is taking up of relevant management practices. The proportion of debt used in an LBO transaction is also significantly positively associated with best management practices, confirming the contention of Jensen (1989) that debt exercises discipline over company managers. The replacement of the incumbent by a new CEO also has significant and positive effects in every specification save target-related practices. As target-related practices are mostly levied at the behest of the buyout sponsors as soon as company changes hand, a new CEO will likely have less influence over the introduction of such practices. On the other hand, operations and incentive related practices are developed over the life of a buyout giving a new CEO an ample opportunity to shape the design and nature of the control process.

\section{$<$ Insert Table 5 about here $>$}

Company size explains the decision to adopt monitoring related practices as there is a statistically significant association between employee headcount, the proxy for company size, and monitoring. Interestingly, size is not significant in target related practice model, which underlines the fact that considerations for the adoption of such practices in a buyout are largely divorced from actual employee numbers. The coefficients of professional staff (i.e., HR Manager, CFO, BD Manager) are positive and significant in all best management practice specifications, indicating that the appointment of professional staff encourages the company to take up a larger number of best management practices. This is also consistent with the idea that the adoption of best management practices in a firm is given boost by the availability of expert help. For example, knowledge of incentives and monitoring practices may form part of the professional toolkit of a human resource manager; thus, in hiring this person, companies are benefiting from his/her expertise in monitoring and incentive related practices.

The findings suggest that the cost leadership is positively and significantly associated with target related practices, confirming the view that performance measurement emphasizing concrete performance targets registers heavily in a buyout's plan to cut costs in its initial phases 
of development. On the other hand, differentiation strategy has a significant and positive association with operations and incentives related practices. These results suggest that different buyout strategies imply different best management practice adoption approaches: when buyouts adopt an internally focused approach, efficiency management and cost control become a priority. In contrast, when product-market variations are greater, incentives and operations become a central concern. As incentives related practices tolerate, if not encourage, experimentation and creativity if set appropriately, buyouts can aim to extend their market reach by focusing on growth and development of new product lines. Similarly, more attention needs to be paid to operations related practice when a firm undergoes changes in its production. The findings shows that the subsidiary is significant in target related regression, whereas its relationships with monitoring and incentives are statistically weak.

Overall, the evidence is consistent with the explanatory variables having significant effects on the adoption of best management practices. Buyouts utilize almost all best management practices intensely, although there may be important variations in the way different best management practice systems are operated in relation to different strategy challenges. The effects of subsidiary, size and new CEO are the only variables where our conclusions are not robust across all specifications.

\subsection{Best Management Practices and Buyout Performance}

The question we want to address in this section is whether the adoption of best management practices has any effect on company performance and productivity as well. Past studies on the implementation of different forms of management systems have usually modelled adoption of these practices in relation to growth in employees (Hambrick, 1983). This is based on the assumption that as the number of employees increases firm demand for formal control systems also increases. However, in the present case, such a measure will give a distorted picture of the effect of employee size, as buyouts generally reduce employment as part of their restructuring programs. Therefore, the study uses growth in revenues, productivity and ROA as the company performance measures. Best management practices are related to operations, monitoring, targets and incentives, as before. Information about these measures, including revenue growth, productivity and ROA, were obtained through the questionnaire survey as well as various secondary sources, as mentioned above.

We control for buyout sponsor's board member, new CEO, Size, HR Manager, CFO, Marketing / Product Development Manager, and Subsidiary. 
Productivity $=\alpha+\beta^{*}$ OPERATIONS $+\beta^{*}$ MONITORING $+\beta *$ TARGETS $+\beta^{*}$ INCENTIVES

$+\beta^{*}$ Control Variables $+\varepsilon$

Table 6 provides OLS (Ordinary Least Square) results for the effects of best management practices on buyout performance. The dependent variable for the first regression is revenue growth (Column 1). For the second and third regressions, the dependent variables are denoted by productivity (Column 2) and ROA (Column 3).

\section{$<$ Insert Table 6 about here >}

For revenue growth, productivity and ROA regressions, the coefficients for all four sets of best management practices are positive and significant, indicating that the adoption of best management practices is indeed associated with improved buyout productivity and performance. The models' $R^{2}$ 's range from 0.112 to $0.560(p<0.001)$. The relationships between different management practices and revenue growth are ambiguous, as the signs are as expected but the coefficients not significant. In addition, the regression model as a whole is not significant, underlining the difficulty in predicting revenue growth. As before, Size, new CEO, Board, CFO, HR Manager, Marketing / Product Development Manager, Cost leadership, Differentiation, Subsidiary and various industry sectors were included in LBO performance regressions. Findings also suggest that the company size, board membership, and new CEO are important as are different categories of professional staff in explaining the variation in performance outcomes. Likewise, strategy variables have significant positive impact on buyout performance. However, the effect of subsidiary on buyout performance is ambiguous, since it has opposite effects for ROA.

\subsection{Endogeneity}

In the empirical analysis, the hiring of professional staff (HR manager, CFO, Marketing / Product Development manager) is modelled as endogenous decisions. Results presented in Table 6 show that professional staff have positive effect on buyout firm performance. It has thus been argued that professional staff increase the odds for investment success. However, this analysis does not take into account the possibility that professional staff are valued only when they affect performance. To account for the endogenous relation between professional staff and performance, we also estimate the performance effect of professional staff with twostage least squares (2SLS). Table 7 provides 2 SLS results, which confirm that professional 
staff indeed raise the buyout firm performance. In fact, the results are stronger than the OLS regressions, especially the association between $\mathrm{CFO}$ and productivity.

\section{$<$ Insert Table 7 about here $>$}

\section{Discussion and Conclusion}

The paper studies best management practices within the context of a restructuring firm. Specifically, the empirical study traces the evolution of best management practices in leveraged buyout companies. Buyouts normally have a life cycle that extends from deal structuring, changes in company management practice, and then, finally, harvesting investment. Underlying these phases of investment is the application of best management practices that reflects the buyout sponsors' concern for creating a re-vitalized focus on performance. Best management practices thus mediate the relationship between buyout investors and their portfolio companies.

By treating best management practices as a tool of firm productivity growth, the present study explores the variation in the types of best management practices introduced by buyout firms. Specifically, the study finds that targets and monitoring are of a particular concern for buyout sponsors in the immediate aftermath of company takeover while operations and incentives appear to be more relevant during periods of buyout expansion involving innovative product market solutions. The findings also show how the varying nature of the quality of expert administrative support available in a firm as well as agency costs significantly influence the need for best management practices. In the regression results, firm size is not associated with targets, underlining the influence of external factors in the take up of target related management practices. The size variable is significant though in monitoring related models. The results also indicate that as buyout firms lay foundations for growth and development and put in place the requisite conditions for investor exit, they rely on incentives and operations more than targets and monitoring related practices for materializing their objectives. Further evidence for this trend comes from the positive associations between incentives and operations and professional staffs.

The above findings provide two main conclusions regarding the application of the theoretical model. First, the adoption of best management practices needs to be understood in relation to how they evolve over time. We find specific evidence that supports the evolutionary and adaptive theories' contention that practices that control and coordinate critical operational processes within organizations evolve over time. It is thus important to understand how 
workplace practices within organizations first emerge and then develop along the firm's evolutionary path (Nelson and Winter, 1982; Ethiraj and Levinthal, 2004). Best management practices may be considered as information-based decision support mechanisms, exhibiting formalized and recurrent structures. As organizational routines (Nelson and Winter, 1982; Bagnoli and Vedovato, 2014; Centobelli et al. 2017a), they provide direction for carrying out activities to accomplish day-to-day operations, and thus help managers perform their functions efficiently and effectively. They may also leverage manager attention to diagnose 'errors' and help evaluate key decisions in the management of personnel and resources (Simons, 1994; Siders et al. 2001; Beersma, et. al. 2003; Durst and Wilhelm, 2012; Inkinen, 2016; Massaro et al., 2016). There can be a few important organizational mechanisms, such as an informationrich knowledge management system, that confer knowledge benefits through the adoption of best management practices. However, these benefits are rarely directly observed and measured. Specific knowledge management theories such as the coordination and codification of knowledge stress the importance of measuring the nature of a particular management system (Centobelli et al. 2017b). This has now been made possible by the availability of digital and social media platforms that allow a large number of individuals to regularly communicate and share information. Moreover, a particular problem with the traditional knowledge management system was that employees felt resistant to knowledge sharing. The emergence of new production systems offer companies opportunities to listen to and engage with their employees, and potentially to encourage them to become long term agents of change through knowledge sharing and development. The current study indicates how best management practices and traditional knowledge management systems interact to create this new concept. It takes the original knowledge management concepts of knowledge sharing and show how best management practices incorporate such specific features to benefit an organization in terms of the increased levels of knowledge sharing and system informativeness. Consequently, policy makers can focus on encouraging the adoption of management practices that particularly enhance the adoption and further development of new knowledge management systems in small scale and medium sized firms. Best management practices thus possess information processing properties that provide structure to an organization's work and lay down roadmap for controlled and consistent performance (Ouchi, 1979; Egeihoff, 1982; Tushman and Nadler, 1986; Grant, 1996). Adaptive organization framework also emphasizes the need for analysing the role of various firm-related change factors in how different management practices are introduced in the first place and what factors induce changes in them (Cyert and March, 1963; Dosi and Marengo, 2007; Cerchione and Esposito, 2017; Centobelli et al. 2017b). For example, 
we find that different firm strategies are linked to different types of management practices as implemented by LBOs in relation to their growth trajectory. Similarly, we show that outside investors' board representatives and new CEO can play an important role in introducing different management practices. The paper therefore argues that any theoretical perspective on management practices must incorporate in its analysis all those factors that are likely to influence the adoption of best management practices.

The results show that best management practices are strongly positively related to manufacturing organizations only. One reason for these results perhaps might be that the best management practices examined by Bloom and Van Reenen (2007) are designed primarily for manufacturing firms only. There is thus a potential opportunity for future research in this area to devise new instruments of best management practices specifically for service sector firms and other similar establishments. Furthermore, the findings shed light on how management practice related production planning and control processes can be managed more efficiently and effectively. For example, at what stage of a firm's production planning and control processes adopt a particular type of best management practices. Moreover, there are other contexts in which best management practices will potentially need to be investigated such as mergers and acquisitions to find a better understanding of the link between management practices and productivity. Similarly, research into more focused management areas such as supply chain management could be undertaken to develop new industry related insights. Research in these areas may highlight other contingency factors that motivate the adoption of best management practices. 
Production Planning \& Control: The Management of Operations 2019;30(10-12):919-934.

\section{References}

Abell, P., Felin, T. \& Nicolai, F. 2008. Building micro-foundations for the routines, capabilities, and performance links. Managerial and Decision Economics, 29 (6): 489-502.

Aboelmaged, M.G. 2014. Linking operations performance to knowledge management capability: The mediating role of innovation performance. Production Planning \& Control: The Management of Operations, 25(1), 44-58.

Bagnoli, C., \& Vedovato, M. 2014. The impact of knowledge management and strategy configuration coherence on SME performance, Journal of Management \& Governance, $18(2), 615-647$.

Bandiera, O., Barankay, I. \& Rasul, I. 2011. Field experiments with firms, Journal of Economic Perspectives, 25(3): 63-82.

Baron, J. N., Burton, M. D., \& Hannan, M. T. 1996. The road taken: origins and evolution of employment systems in emerging companies. Industrial and Corporate Change, 5: $239-275$.

Bertrand, M., \& Schoar, A. 2003. Managing with style: The effect of managers on firm policies, Quarterly Journal of Economics, 118 (4): 1169-1208.

Black, S., \& Lynch, L. 2001. How to compete: The impact of workplace practices and information technology on productivity, Review of Economics and Statistics, 83(3): 434-445.

Bloom, N., Eifert, B., Mahajan, A., McKenzie, D. \& Roberts, J. 2011. Does management matter? Evidence from India. NBER Working Paper 16658.

Bloom, N. \& Van Reenen, J. 2007. Measuring and explaining management practices across firms and countries, The Quarterly Journal of Economics, 122(4): 1351-1408.

Bloom, N. \& Van Reenen, J. 2010. Why do management practices differ across firms and countries? Journal of Economic Perspectives, 2010, 24: 203-24.

Bouvier L. \& Nisar, T. 2012. Managerial capital and firm types: Findings from private bond contracts, Applied Economics Letters, 20(6): 592-595.

Bruining, J. \& Wright, M. 2002. Entrepreneurial orientation in management buy-outs and the contribution of venture capital. Venture Capital 4: 147-168.

Centobelli, P., Cerchione, R., \& Esposito. 2017a. Knowledge management systems: the hallmark of SMEs, Knowledge Management Research and Practice, doi: $10.1057 / \mathrm{s} 41275-017-0054-\mathrm{X}$ 
Centobelli P., Cerchione R., \& Esposito, E. 2017b. Knowledge Management in Startups: Systematic Literature Review and Future Research Agenda, Sustainability, 9, 361.

Cerchione R., \& Esposito E. 2017. Using Knowledge Management Systems: A Taxonomy of SME Strategies, International Journal of Information Management, 37, 1551-1562.

Chandler, A. D. 1962. Strategy and structure: Chapters in the history of the industrial enterprise. Cambridge, Massachusetts: MIT Press.

Child, J., \& Mansfield, R. 1972. Technology, size and organizational structure. Sociology, 6: 369-393.

Cornelli, F. \& Karakas, O. 2008. Private equity and corporate governance: Do LBOs have more effective boards? The Global Economic Impact of Private Equity Report 2008, World Economic Forum.

Cumming, D. Siegel, D.S. \& Wright, M. 2007. Private equity, leveraged buyouts and governance. Journal of Corporate Finance, 13: 439-460.

Cyert, R. M., \& March, J. G. 1963. A behavioral theory of the firm. Englewood Cliffs, NJ: Prentice-Hall.

DiMaggio, P. J. \& Powell, W. W. 1983. The iron cage revisited: Institutional isomorphism and collective rationality in organizational fields, American Sociological Review, 48, 147160.

Durst, S., Aggestam, L., \& Ferenhof, H.A. 2015. Understanding knowledge leakage: a review of previous studies VINE, $45 \quad$ (4), pp. 568-586. Durst, S., \& Wilhelm, S. 2012. Knowledge management and succession planning in SMEs (2012) Journal of Knowledge Management, 16 (4), pp. 637-649.

Edvardsson, I.R., \& Durst, S. 2014. Outsourcing of knowledge processes: A literature review, Journal of Knowledge Management, 18 (4), pp. 795-811.

Egeihoff, W. G. 1982. Strategy and structure in multinational corporations: An information processing approach. Administrative Science Quarterly, 27: 435-458.

Ethiraj, S. \& Levinthal, D. A. 2004. Bounded rationality and the search for organizational architecture: An evolutionary perspective on the design of organizations and their evolvability, Administrative Science Quarterly, 49: 404-437.

Fox, I. \& Marcus, A. 1992. The causes and consequences of leveraged management buyouts. Academy of Management Review, 17: 62-85.

Gabarro, J. J. 1987. The Dynamics of taking charge. Boston: Harvard Business School Press.

Gertner R. \& Kaplan S. 1996. The value maximizing board. University of Chicago, working paper. 
Govindarajan, V. \& Fisher, J. 1990. Strategy, control systems, and resource sharing: Effects on business-unit performance, The Academy of Management Journal, 33: 259-285.

Greene, W. H. 2000. Econometric analysis. Upper Saddle River, NJ: Prentice-Hall.

Greiner, Larry E. 1972. Evolution and revolution as organizations grow. Harvard Business Review. 76: 55-68.

Halpern, P., Kieschnick, R. \& Rotenberg, W. 1999. On the heterogeneity of leveraged going private transactions. The Review of Financial Studies, 2: 281-309.

Hambrick, O. C. 1983. High profit strategies in mature capital goods industries: A contingency approach. Academy of Management Journal, 26: 687-707.

Hanna, V., \& Jackson, J. 2015. An examination of the strategic and operational impact of global sourcing on UK small firms. Production Planning \& Control: TheManagement of Operations. 26(10), 786-798.

Hellmann, T., \& Puri, M. 2002. Venture capital and the professionalization of start-up firms: Empirical evidence. Journal of Finance, 57: 169-198.

Herremans, I.M., Isaac, R.G., Kline, T.J.B \& Nazari, J.A. 2011. Intellectual capital and uncertainty of knowledge: Control by design of the management system, Journal of Business Ethics, 98(4): 627-640.

Hill, C. W. 1988. Differentiation versus low cost or differentiation and low cost: A contingency framework. The Academy of Management Review, 13: 401-412.

Hill, C. W., \& Hoskisson, R. E. 1987. Strategy and structure in the multiproduct firm. Academy of Management Review, 12: 331-341.

Holthausen, R. \& Larcker, D. 1996. The financial performance of reversed leverage buyouts. Journal of Financial Economics, 42: 293-332

Huselid, M. A. 1995, The impact of human resource management practices on turnover, productivity, and corporate financial performance, The Academy of Management Journal, 38: (3): 635-672

Inkinen, H. 2016. Review of empirical research on knowledge management practices and firm performance, Journal of Knowledge Management, 20 (2), pp. 230-257.

Jensen, M.C., 1989. Eclipse of the public corporation. Harvard Business Review, 67: 61-74.

Jensen, M.C., 1993. The modern industrial revolution, exit and the failure of internal control systems. Journal of Finance, 48: 831-880.

Jick, T.D. 1979. Mixing qualitative and quantitative methods: Triangulation in action. Administrative Science Quarterly, 24: 602-611 
Jin, L. \& Wang, F. 2002. Leveraged buyouts: inception, evolution, and future trends. Perspective, 3: 3-22.

Jones, G. R. \& Butler, J. E. 1988. Cost, revenue, and business-level strategy. The Academy of Management Review, 13: 202-213.

Kaplan, S. 1989. The effects of management buyouts on operating performance and value. Journal of Financial Economics. 24: 217-254.

Kaplan, S. 1991. The staying power of leveraged buyouts. Journal of Financial Economics, 29: $287-313$.

Kaplan, S. 2007. Private equity: Past, present, and future. Journal of Applied Corporate Finance, 19: 8-16.

Kaplan, S. \& Strömberg, P. 2009. Leveraged buyouts and private equity. Journal of Economic Perspectives, 23: 121-146.

Kotzab, H., Teller, C., Grant, D.B. and Friis, A. (2015)Supply chain management resources, capabilities and execution, Production Planning \& Control 26(7): 525-542.

Langfield-Smith, K. 1997. Management control systems and strategy: a critical review, Accounting, Organizations and Society, 22: 207-232.

Lorsch, J. W., \& Morse, J. J. 1974. Organizations and their members: A contingency approach. New York: Harper \& Row.

March, J. G. \& Simon, H. A. 1958. Organizations. Wiley: New York.

Massaro, M., Handley, K., Bagnoli, C., \& Dumay, J. 2016. Knowledge management in small and medium enterprises: a structured literature review, Journal of Knowledge Management, 20 (2), pp. 258-291.

Miles, R. E., \& Snow, C. C. 1978. Organization strategy, structure and process. New York: McGraw-Hill.

Murray, A. I. 1988. A contingency view of Porter's generic strategies. Academy of Management Review. 13: 390-400.

Nelson, R. \& S. Winter. 1982. An evolutionary theory of economic change. Cambridge, Massachusetts: Harvard University Press.

Osborn, R. N. \& Hagedoorn, 1997. The institutionalization and evolutionary dynamics of interorganizational alliances and networks. Academy of Management Journal, 40:261278.

Phan, P. \& Hill, C., 1995. Organizational restructuring and economic performance in leveraged buyouts: An ex post study. Academy of Management Journal, 38: 704-739.

Porter, M. 1980. Competitive Strategy. New York, NY: The Free Press. 
Production Planning \& Control: The Management of Operations 2019;30(10-12):919-934.

Robbie, K. \& Wright, M. 1996. Management buy-ins: entrepreneurship, active investors and corporate restructuring. Manchester: MUP.

Sandino, T. 2007. Introducing the first management control systems: Evidence from the retail sector. The Accounting Review, 82:1, 265-293.

Seidman, I. 1998. Interviewing as qualitative research: A guide for researchers in education and the social sciences. New York, NY: Teachers College Press

Simons, R. 1994. How New top managers use control systems as levers of strategic renewal. Strategic Management Journal, 15: 169-189.

Snow, C. C, \& Hrebiniak, L. G. 1980. Strategy, distinctive competence, and organizational performance. Administrative Science Quarterly, 25: 317-335.

Strang, D., \& Still, M. C. 2004, In Search of the elite: Revising a model of adaptive emulation with evidence from benchmarking teams, Industrial and Corporate Change, 13: 30933.

Syverson, C. 2004. Market structure and productivity: A concrete example, Journal of Political Economy, 112(6): 1181-1222.

Syverson, C. 2011. What determines productivity? Journal of Economic Literature, 49(2): $326-365$.

Williamson, O. E. 1971. The vertical integration of production: Market failure considerations. American Economic Review, 61: 112-23.

Zhang, M., Pawar, K.S. and Bhardwaj, S. (2017) Improving supply chain social responsibility through supplier development, Production Planning \& Control, 28(6-8): 500-511. 
Production Planning \& Control: The Management of Operations 2019;30(10-12):919-934.
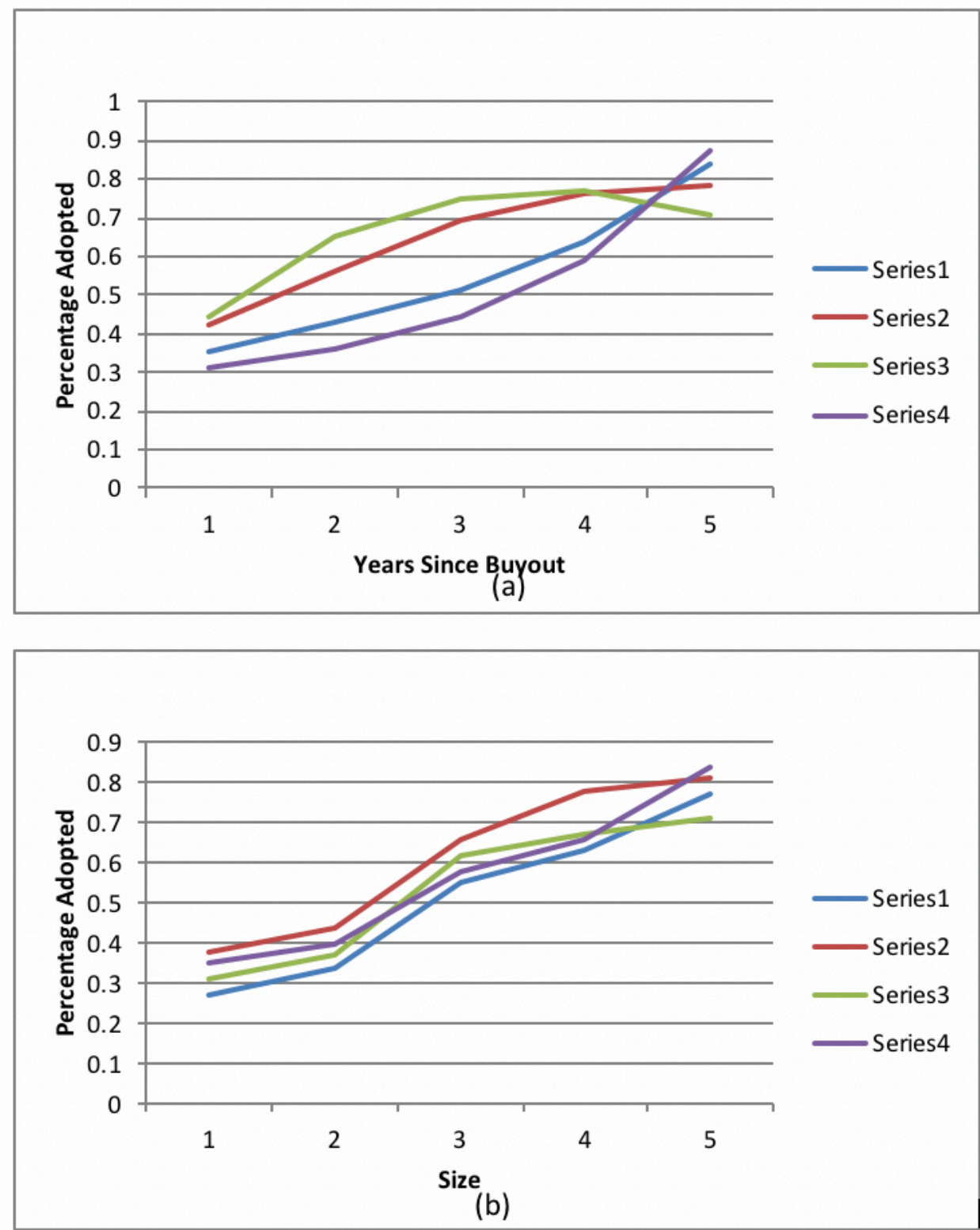

Figure 1: Adoption of best management practices (BMP): (a) BMP and buyout firm's age; (b) BMP and buyout firm's size 
Production Planning \& Control: The Management of Operations 2019;30(10-12):919-934.
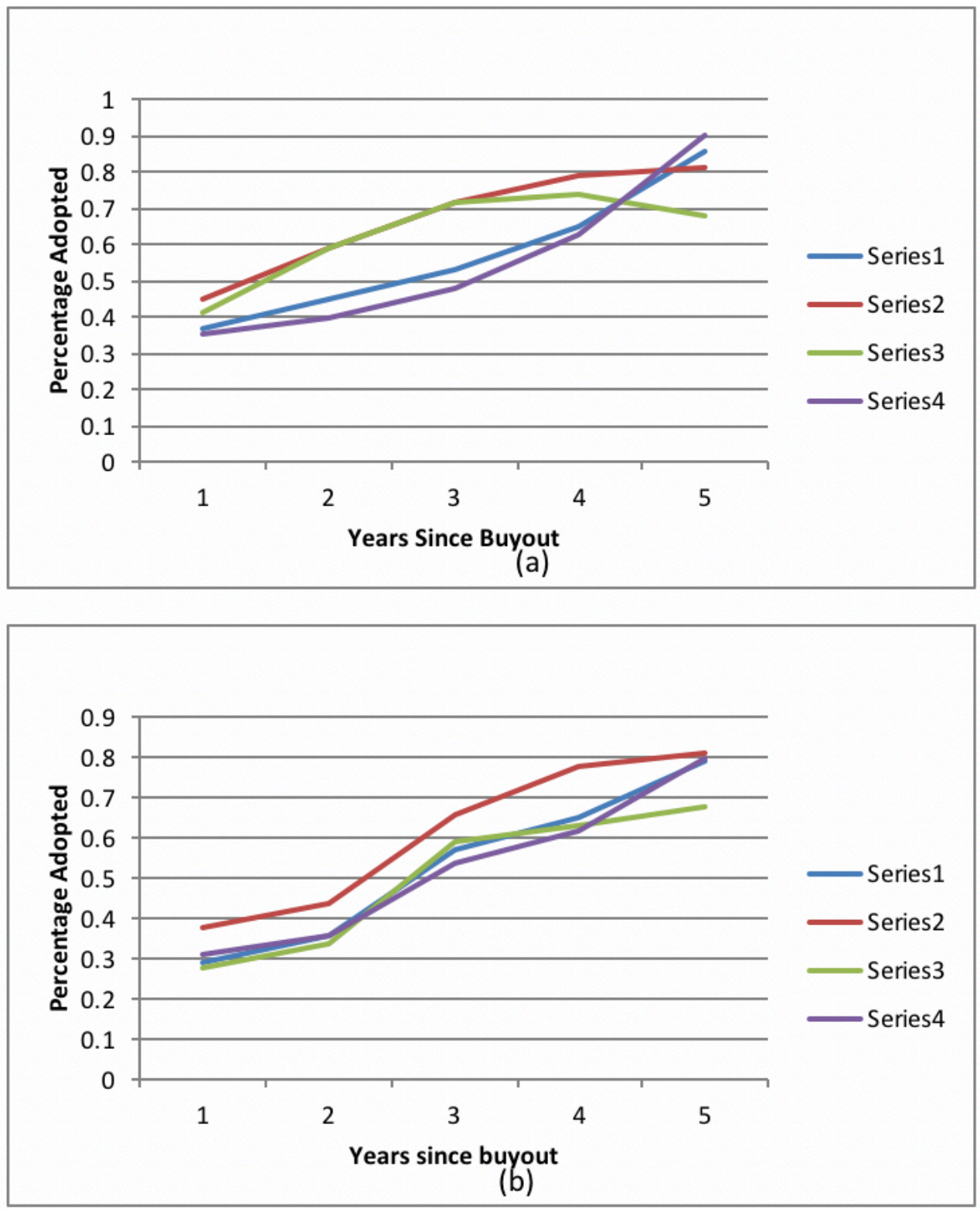

Figure 2: Adoption of best management practices: (a) BMP and buyout age in MBOs; (b) BMP and buyout age in non-MBOs. 
Production Planning \& Control: The Management of Operations 2019;30(10-12):919-934.

Table 1: Adaptive organizations and best management practices

\begin{tabular}{|c|c|c|c|}
\hline $\begin{array}{l}\text { Areas where } \\
\text { adaptive processes } \\
\text { are likely to occur }\end{array}$ & $\begin{array}{l}\text { Information-based } \\
\text { decision support } \\
\text { organizational } \\
\text { mechanisms }\end{array}$ & $\begin{array}{l}\text { Resource allocation } \\
\text { related } \\
\text { organizational } \\
\text { mechanisms }\end{array}$ & $\begin{array}{l}\text { Performance } \\
\text { measurement related } \\
\text { organizational } \\
\text { mechanisms }\end{array}$ \\
\hline \multirow[t]{4}{*}{$\begin{array}{l}\text { Best management } \\
\text { practices }\end{array}$} & $\begin{array}{l}\text { Operations related } \\
\text { management } \\
\text { practices }\end{array}$ & $\begin{array}{l}\text { Incentives related } \\
\text { management } \\
\text { practices }\end{array}$ & $\begin{array}{l}\text { Targets related } \\
\text { management } \\
\text { practices, including } \\
\text { the type of targets, } \\
\text { realism of the } \\
\text { targets, the } \\
\text { transparency of } \\
\text { targets and the range } \\
\text { and interconnection } \\
\text { of targets }\end{array}$ \\
\hline & $\begin{array}{l}\text { The introduction of } \\
\text { lean manufacturing } \\
\text { techniques }\end{array}$ & Promotion criteria & $\begin{array}{l}\text { Monitoring related } \\
\text { management } \\
\text { practices, including } \\
\text { the tracking of } \\
\text { performance of } \\
\text { individuals, } \\
\text { reviewing } \\
\text { performance and } \\
\text { consequence } \\
\text { management }\end{array}$ \\
\hline & $\begin{array}{l}\text { The documentation } \\
\text { of processes } \\
\text { improvements }\end{array}$ & Pay and bonuses & \\
\hline & $\begin{array}{l}\text { The rationale behind } \\
\text { introductions of } \\
\text { improvements }\end{array}$ & $\begin{array}{l}\text { Fixing or firing bad } \\
\text { performers }\end{array}$ & \\
\hline
\end{tabular}


Production Planning \& Control: The Management of Operations 2019;30(10-12):919-934.

Table 2: Sample development

\begin{tabular}{|l|c|}
\hline Companies in the initial database & 520 \\
\hline Companies that went out of business & 16 \\
\hline Companies acquired & 72 \\
\hline Companies ineligible in some other way $^{\mathrm{a}}$ & 49 \\
\hline Companies that did not respond $^{\mathrm{b}}$ & 48 \\
\hline Companies that declined participation & 127 \\
\hline Final sample of companies & $\mathbf{2 0 8}$ \\
\hline
\end{tabular}

a: These are companies that are too old, or have trade union problems.

b: These are companies that did not respond at all. 
Production Planning \& Control: The Management of Operations 2019;30(10-12):919-934.

Table 3: Descriptive statistics

\begin{tabular}{|c|c|c|c|c|c|}
\hline Variables & Year 1 & Year 2 & Year 3 & Year 4 & Year 5 \\
\hline $\begin{array}{l}\text { BMP } \\
\text { Mean } \\
\text { Std. Dev }\end{array}$ & $\begin{array}{l}0.38 \\
0.18\end{array}$ & $\begin{array}{l}0.50 \\
0.19\end{array}$ & $\begin{array}{l}0.60 \\
0.20\end{array}$ & $\begin{array}{l}0.69 \\
0.20\end{array}$ & $\begin{array}{l}0.80 \\
0.21\end{array}$ \\
\hline $\begin{array}{l}\text { Operations }{ }^{\mathrm{a}} \\
\text { Mean } \\
\text { Std. Dev }\end{array}$ & $\begin{array}{l}0.35 \\
0.26\end{array}$ & $\begin{array}{l}0.43 \\
0.26\end{array}$ & $\begin{array}{l}0.51 \\
0.27\end{array}$ & $\begin{array}{l}0.64 \\
0.28\end{array}$ & $\begin{array}{l}0.84 \\
0.26\end{array}$ \\
\hline $\begin{array}{l}\text { Monitoring } \\
\text { Mean } \\
\text { Std. Dev }\end{array}$ & $\begin{array}{l}0.42 \\
0.26\end{array}$ & $\begin{array}{l}0.56 \\
0.28\end{array}$ & $\begin{array}{l}0.69 \\
0.28\end{array}$ & $\begin{array}{l}0.76 \\
0.27\end{array}$ & $\begin{array}{l}0.78 \\
0.24\end{array}$ \\
\hline $\begin{array}{l}\text { Targets } \\
\text { Mean } \\
\text { Std. Dev }\end{array}$ & $\begin{array}{l}0.44 \\
0.24\end{array}$ & $\begin{array}{l}0.65 \\
0.23\end{array}$ & $\begin{array}{l}0.75 \\
0.24\end{array}$ & $\begin{array}{l}0.77 \\
0.24\end{array}$ & $\begin{array}{l}0.71 \\
0.24\end{array}$ \\
\hline $\begin{array}{l}\text { Incentives } \\
\text { Mean } \\
\text { Std. Dev } \\
\end{array}$ & $\begin{array}{l}0.31 \\
0.28\end{array}$ & $\begin{array}{l}0.36 \\
0.28\end{array}$ & $\begin{array}{l}0.44 \\
0.26\end{array}$ & $\begin{array}{l}0.59 \\
0.27\end{array}$ & $\begin{array}{l}0.87 \\
0.26\end{array}$ \\
\hline $\begin{array}{l}\text { Size } \\
\text { Mean } \\
\text { Median } \\
\text { Std. Dev } \\
\end{array}$ & $\begin{array}{l}76.30 \\
42 \\
175.45\end{array}$ & $\begin{array}{l}71.61 \\
63 \\
238.39\end{array}$ & $\begin{array}{l}197.30 \\
86 \\
220.77\end{array}$ & $\begin{array}{l}386.78 \\
120 \\
412.37\end{array}$ & $\begin{array}{l}523.85 \\
126 \\
585.65\end{array}$ \\
\hline $\begin{array}{l}\text { BOARD } \\
\text { Mean }\end{array}$ & 0.71 & 0.73 & 0.73 & 0.77 & 0.76 \\
\hline $\begin{array}{l}\text { DEBT } \\
\text { Mean }\end{array}$ & 0.66 & 0.72 & 0.65 & 0.61 & 0.54 \\
\hline $\begin{array}{l}\text { CEO } \\
\text { Mean }\end{array}$ & 0.33 & 0.35 & 0.35 & 0.54 & 0.52 \\
\hline $\begin{array}{l}\text { CFO } \\
\text { Mean }\end{array}$ & 0.34 & 0.38 & 0.25 & 0.49 & 0.58 \\
\hline $\begin{array}{l}\text { HR MANAGER } \\
\text { Mean }\end{array}$ & 0.65 & 0.78 & 0.64 & 0.53 & 0.47 \\
\hline $\begin{array}{l}\text { BD MANAGER } \\
\text { Mean }\end{array}$ & 0.17 & 0.56 & 0.45 & 0.76 & 0.58 \\
\hline $\begin{array}{l}\text { COMPETITION } \\
\text { Mean }\end{array}$ & 0.65 & 0.66 & 0.65 & 0.63 & 0.63 \\
\hline COST LEADERSHIP & \multicolumn{5}{|c|}{$\begin{array}{l}\text { Std. Dev }=0.72 \\
\text { Actual Range }=-1.89-1.53 \\
\text { Cronbach's } \alpha=0.71\end{array}$} \\
\hline DIFFERENTIATION & \multicolumn{5}{|c|}{$\begin{array}{l}\text { Std. Dev }=0.81 \\
\text { Actual Range }=-2.54-2.17 \\
\text { Cronbach's } \alpha=0.84\end{array}$} \\
\hline $\begin{array}{l}\text { SUBSIDIARY } \\
\text { Mean }\end{array}$ & 0.23 & 0.17 & 0.20 & 0.24 & 0.27 \\
\hline $\begin{array}{l}\text { Productivity } \\
\text { Mean }\end{array}$ & 34.9 & & & & \\
\hline $\begin{array}{l}\text { ROA } \\
\text { Mean }\end{array}$ & 22.7 & & & & \\
\hline $\begin{array}{l}\text { Revenues ('000) } \\
\text { Mean }\end{array}$ & 11,869 & & & & \\
\hline Industry & $\begin{array}{l}\text { Number of } \\
\text { companies }\end{array}$ & & & & \\
\hline Manufacturing & 52 & & & & \\
\hline Trade & 58 & & & & \\
\hline
\end{tabular}


Production Planning \& Control: The Management of Operations 2019;30(10-12):919-934.

\begin{tabular}{|l|l|l|l|l|l|}
\hline Telecommunications & 26 & & & & \\
\hline Health \& Education & 40 & & & & \\
\hline IT Industry & 32 & & & & \\
\hline
\end{tabular}

Notes: a: Operations, Monitoring, Targets and Incentive are the percentage of practices adopted over the maximum number of practices that can be potentially adopted.

b: Revenues are for the last year of data available. 
Production Planning \& Control: The Management of Operations 2019;30(10-12):919-934.

Table 4: Correlation Matrix

\begin{tabular}{|l|llllllllll|}
\hline & SIZE & BOARD & DEBT & CEO & CFO & SUB & BMP & OPER & MON & TAR \\
\hline BOARD & 0.48 & & & & & & & & & \\
DEBT & 0.17 & 0.65 & & & & & & & & \\
CEO & 0.36 & 0.32 & 0.29 & & & & & & & \\
CFO & 0.42 & 0.52 & 0.38 & 0.23 & & & & & & \\
SUBSIDIARY & 0.24 & 0.53 & 0.26 & 0.20 & 0.48 & & & & & \\
BMP & 0.28 & 0.58 & 0.24 & 0.31 & 0.35 & 0.24 & & & & \\
OPERATIONS & 0.48 & 0.63 & 0.49 & 0.54 & 0.57 & 0.48 & 0.37 & & & \\
MONITORING & 0.32 & 0.45 & 0.28 & 0.43 & 0.75 & 0.52 & 0.39 & 0.47 & & \\
TARGETS & 0.16 & 0.61 & 0.57 & 0.22 & 0.62 & 0.54 & 0.31 & 0.52 & 0.53 & \\
INCENTIVES & 0.13 & 0.55 & 0.28 & 0.34 & 0.38 & 0.41 & 0.35 & 0.64 & 0.49 & 0.21 \\
\hline
\end{tabular}

Note: Pearson correlation is reported. All correlations are significant at the $1 \%$ level. 
Table 5: Buyout adoption of BMP

\begin{tabular}{|c|c|c|c|c|c|c|c|c|c|c|}
\hline & \multicolumn{2}{|c|}{ BMP } & \multicolumn{2}{|c|}{ Operations } & \multicolumn{2}{|c|}{ Monitoring } & \multicolumn{2}{|c|}{ Targets } & \multicolumn{2}{|c|}{ Incentives } \\
\hline & Coeff. & Z-stat & Coeff. & Z-stat & Coeff. & Z-stat & Coeff. & Z-stat & Coeff. & Z-stat \\
\hline SIZE & $1.21 * *$ & 0.58 & $0.68 * *$ & 0.76 & $2.44 * * *$ & 1.24 & 0.16 & -0.15 & $1.342 * * *$ & 0.56 \\
\hline BOARD & $1.38 * *$ & 2.74 & $1.52 * *$ & 1.86 & $2.36 * * *$ & 1.65 & $1.74 * * *$ & 1.48 & $1.54 * *$ & 0.64 \\
\hline DEBT & $1.26 * *$ & 0.76 & $1.39 * * *$ & 1.23 & $1.87 * *$ & 1.35 & $1.43 * *$ & 0.58 & $2.76 * * *$ & 1.34 \\
\hline CEO & $1.14^{*}$ & 0.11 & $1.85 * * *$ & 0.01 & 0.54 & 0.03 & 0.12 & -0.67 & $1.58 * * *$ & 1.13 \\
\hline $\mathrm{CFO}$ & $1.79 * *$ & 2.49 & $1.32 * *$ & 3.11 & $1.21 * *$ & 1.18 & $2.27 * * *$ & 1.31 & $1.42 * *$ & 0.28 \\
\hline HR MANAGER & $1.64 * *$ & 0.22 & $3.65 * * *$ & 1.34 & $3.86 * * *$ & 5.06 & $1.16 * *$ & 4.51 & $1.54 * * *$ & 1.49 \\
\hline BD MANAGER & $1.84^{*}$ & 1.31 & $1.12^{* *}$ & 1.15 & $4.25 * * *$ & 2.76 & $1.52 * *$ & 1.82 & $1.53 * * *$ & 1.47 \\
\hline COMPETITION & $1.68 * *$ & 1.47 & 0.31 & 0.50 & $1.65^{* *}$ & 0.45 & $1.48 * *$ & 1.24 & $1.37 * * *$ & 1.26 \\
\hline COSTLEADERSHIP & $1.03 * *$ & 0.01 & $1.06 * *$ & 0.02 & 0.03 & 0.18 & $3.67 * * *$ & 3.31 & 0.01 & 0.02 \\
\hline DIFFERENTIATION & $2.25 * *$ & 0.82 & $2.28 * * *$ & 0.68 & 0.08 & 0.12 & 0.21 & -0.91 & $1.26 * * *$ & 0.12 \\
\hline SUBSIDIARY & 1.03 & 0.17 & 0.82 & 0.14 & 0.04 & -0.12 & $1.32 * * *$ & 0.21 & $1.45 * * *$ & 1.13 \\
\hline Manufacturing & $1.86^{* * *}$ & 1.31 & $1.30 * * *$ & 0.35 & $1.46 * * *$ & 0.21 & $1.69 * * *$ & 3.60 & $1.12 * * *$ & 1.59 \\
\hline Trade & 0.05 & 0.29 & 0.93 & 0.89 & 0.73 & 0.49 & 0.78 & -1.60 & 0.86 & 0.69 \\
\hline Telecom & 0.91 & -0.53 & $0.74 *$ & -1.87 & 0.83 & -1.25 & 0.80 & -1.55 & 0.36 & 0.70 \\
\hline Health \& Education & 0.73 & -2.17 & 0.94 & 0.60 & 0.90 & -0.89 & $-1.47^{*}$ & 3.51 & 0.25 & 1.43 \\
\hline IT Industry & 0.96 & -0.33 & 0.80 & -1.55 & 1.27 & 1.25 & 0.81 & -1.79 & $0.02 *$ & 0.54 \\
\hline
\end{tabular}


Production Planning \& Control: The Management of Operations 2019;30(10-12):919-934.

Table 6: Best management practices and buyout firm performance.

\begin{tabular}{|c|c|c|c|}
\hline & Revenue Growth & Productivity & ROA \\
\hline \multirow[t]{2}{*}{ CONSTANT } & $1.197^{*}$ & $1.691 * * *$ & $0.351 * * *$ \\
\hline & $(0.441)$ & $(0.559)$ & $(1.016)$ \\
\hline \multirow[t]{2}{*}{ OPERATIONS } & 0.003 & $0.531 * * *$ & $0.383 * * *$ \\
\hline & $(0.112)$ & $(0.455)$ & $(0.541)$ \\
\hline \multirow[t]{2}{*}{ MONITORING } & 0.111 & $1.647 * * *$ & $0.372 * *$ \\
\hline & $(0.143)$ & $(0.482)$ & $(0.282)$ \\
\hline \multirow[t]{2}{*}{ TARGETS } & $0.012^{*}$ & $1.536 * * *$ & $1.831 * * *$ \\
\hline & (1.284) & $(0.338)$ & $(0.986)$ \\
\hline \multirow[t]{2}{*}{ INCENTIVES } & 0.023 & $1.363 * * *$ & $1.654 * *$ \\
\hline & $(0.024)$ & $(0.571)$ & $(0.645)$ \\
\hline \multirow[t]{2}{*}{ SIZE } & $0.219^{*}$ & $0.771 * * *$ & $0.631 * * *$ \\
\hline & $(0.164)$ & $(0.153)$ & $(0.581)$ \\
\hline \multirow[t]{2}{*}{ BOARD } & 0.066 & $0.841 * * *$ & $0.536 * * *$ \\
\hline & $(0.162)$ & $(0.512)$ & $(0.432)$ \\
\hline \multirow[t]{2}{*}{ DEBT } & 0.024 & $0.152 * * *$ & $0.641 * * *$ \\
\hline & $(0.036)$ & $(0.142)$ & $(0.234)$ \\
\hline \multirow[t]{2}{*}{ CEO } & 0.002 & $0.298 * * *$ & $0.017 *$ \\
\hline & (1.202) & $(0.020)$ & $(0.033)$ \\
\hline \multirow[t]{2}{*}{ HR MANAGER } & 0.142 & $0.253 * * *$ & $0.109 * *$ \\
\hline & $(0.101)$ & $(0.139)$ & $(0.085)$ \\
\hline \multirow[t]{2}{*}{$\mathrm{CFO}$} & 0.105 & $0.149 * * *$ & 0.002 \\
\hline & $(0.021)$ & $(0.376)$ & $(0.117)$ \\
\hline \multirow[t]{2}{*}{ BD MANAGER } & 0.171 & 0.231 & $0.232 * *$ \\
\hline & $(0.049)$ & $(0.153)$ & $(0.357)$ \\
\hline \multirow[t]{2}{*}{ COMPETITION } & $0.182 * *$ & $1.451 * *$ & $0.672 * * *$ \\
\hline & $(0.138)$ & $(0.512)$ & $(0.324)$ \\
\hline \multirow[t]{2}{*}{ COSTLEADERSHIP } & 0.105 & $3.342 * * *$ & $1.256 * *$ \\
\hline & $(0.016)$ & $(0.618)$ & $(0.781)$ \\
\hline \multirow[t]{2}{*}{ DIFFERENTIATION } & $0.116^{*}$ & $2.671 * * *$ & $2.341 * * *$ \\
\hline & $(0.218)$ & $(0.357)$ & $(0.873)$ \\
\hline \multirow[t]{2}{*}{ SUBSIDIARY } & 0.005 & 0.231 & -0.031 \\
\hline & $(0.029)$ & $(0.181)$ & $(0.171)$ \\
\hline Industry Controls & Yes & Yes & Yes \\
\hline Observations & 207 & 208 & 208 \\
\hline P-value of F-Statistic & 0.006 & 0.009 & 0.013 \\
\hline $\mathrm{R}^{2}$ & $0.112 * * *$ & $0.560 * * *$ & $0.346^{* * *}$ \\
\hline
\end{tabular}

Note: The standard errors and covariances are white heteroskedasticity-consistent. In all regressions, industry controls are included but not reported. (*** $\mathrm{p}<0.01$;** $^{*}<0.05$; $\left.^{*} \mathrm{p}<0.1\right)$ 
Production Planning \& Control: The Management of Operations 2019;30(10-12):919-934.

Table 7: Endogeneity - Best management practices and buyout firm performance

\begin{tabular}{|c|c|c|c|}
\hline & Revenue Growth & Productivity & ROA \\
\hline \multirow[t]{2}{*}{ Constant } & 0.186 & 0.008 & $0.027^{*}$ \\
\hline & $(0.131)$ & $(0.513)$ & $(0.930)$ \\
\hline \multirow[t]{2}{*}{ OPERATIONS } & 0.198 & $1.180 * * *$ & $0.691 * * *$ \\
\hline & $(0.160)$ & $(0.792)$ & $(0.530)$ \\
\hline \multirow[t]{2}{*}{ MONITORING } & 0.058 & $0.147 * * *$ & $0.156 * * *$ \\
\hline & $(0.023)$ & $(0.134)$ & $(0.041)$ \\
\hline \multirow[t]{2}{*}{ TARGETS } & 0.056 & $0.474 * * *$ & $1.277 * * *$ \\
\hline & $(0.164)$ & $(0.226)$ & $(0.612)$ \\
\hline \multirow[t]{2}{*}{ INCENTIVES } & $0.279 * *$ & $1.083 * * *$ & $1.031 * * *$ \\
\hline & $(0.036)$ & $(0.961)$ & $(0.420)$ \\
\hline \multirow[t]{2}{*}{ SIZE } & 0.218 & $0.832 * * *$ & $0.460 * *$ \\
\hline & $(0.283)$ & $(0.529)$ & $(0.434)$ \\
\hline \multirow[t]{2}{*}{ BOARD } & 0.094 & $0.410 * * *$ & $0.191 * *$ \\
\hline & $(0.215)$ & $(0.351)$ & $(0.133)$ \\
\hline \multirow[t]{2}{*}{ DEBT } & 0.118 & $0.203 * *$ & $0.774 * * *$ \\
\hline & $(0.112)$ & $(0.134)$ & $(0.678)$ \\
\hline \multirow[t]{2}{*}{ CEO } & 0.124 & $0.378 * *$ & $0.216^{* * *}$ \\
\hline & $(0.221)$ & $(0.257)$ & $(0.114)$ \\
\hline \multirow[t]{2}{*}{ HR MANAGER } & 0.186 & $0.212 * * *$ & $0.264 * * *$ \\
\hline & $(0.131)$ & $(0.161)$ & $(0.142)$ \\
\hline \multirow[t]{2}{*}{$\mathrm{CFO}$} & 0.203 & $2.955 * * *$ & $0.210 * * *$ \\
\hline & $(0.255)$ & $(1.175)$ & $(0.116)$ \\
\hline \multirow[t]{2}{*}{ BD MANAGER } & 0.170 & $0.261 * *$ & 0.001 \\
\hline & $(0.142)$ & $(0.171)$ & $(0.001)$ \\
\hline \multirow[t]{2}{*}{ COMPETITION } & 0.001 & $0.278 * * *$ & $0.169 * * *$ \\
\hline & $(0.003)$ & $(0.173)$ & $(0.136)$ \\
\hline \multirow[t]{2}{*}{ COSTLEADERSHIP } & 0.115 & $0.236 * * *$ & $0.233 *$ \\
\hline & $(0.109)$ & $(0.244)$ & $(0.43)$ \\
\hline \multirow[t]{2}{*}{ DIFFERENTIATION } & 0.130 & $0.278 * * *$ & $0.175 * *$ \\
\hline & $(0.137)$ & $(0.114)$ & $(0.085)$ \\
\hline \multirow[t]{2}{*}{ SUBSIDIARY } & 0.001 & 0.163 & -0.001 \\
\hline & $(0.003)$ & $(0.149)$ & $(0.007)$ \\
\hline Industry Controls & Yes & Yes & Yes \\
\hline Observations & 207 & 208 & 208 \\
\hline P-value of F- & 0.011 & 0.007 & 0.011 \\
\hline \multicolumn{4}{|l|}{ Statistics } \\
\hline $\mathrm{R}^{2}$ & $0.118 * * *$ & $0.361 * * *$ & $0.589 * * *$ \\
\hline
\end{tabular}

Notes: The standard errors and covariances are White heteroskedasticity-consistent. In all regressions, industry controls are included but not reported. $\left(* * * \mathrm{p}<0.01\right.$; $\left.^{* *} \mathrm{p}<0.05 ; * \mathrm{p}<0.1\right)$. 
Production Planning \& Control: The Management of Operations 2019;30(10-12):919-934.

\begin{tabular}{|c|c|c|c|}
\hline Scoring Grid & 1 & 3 & 5 \\
\hline $\begin{array}{l}\text { Operations - } \\
\text { "Process } \\
\text { improvement } \\
\text { documentation" }\end{array}$ & $\begin{array}{l}\text { No process } \\
\text { improvements made } \\
\text { when problems } \\
\text { occur }\end{array}$ & $\begin{array}{l}\text { Improvements are } \\
\text { made in weekly } \\
\text { workshops involving } \\
\text { all staff, to improve } \\
\text { performance in their } \\
\text { area of the plant }\end{array}$ & $\begin{array}{l}\text { Exposing problems in a } \\
\text { structured way is integral to } \\
\text { individuals' responsibilities, } \\
\text { and resolution occurs as a } \\
\text { part of normal business } \\
\text { processes rather than by } \\
\text { extraordinary effort/teams }\end{array}$ \\
\hline $\begin{array}{l}\text { Monitoring - "How } \\
\text { is Performance } \\
\text { Tracked?" }\end{array}$ & $\begin{array}{l}\text { Measures tracked do } \\
\text { not indicate directly } \\
\text { if overall business } \\
\text { objectives are being } \\
\text { met. Certain } \\
\text { processes are not } \\
\text { tracked at all }\end{array}$ & $\begin{array}{l}\text { Most key } \\
\text { performance } \\
\text { indicators are } \\
\text { tracked formally. } \\
\text { Tracking is overseen } \\
\text { by senior } \\
\text { management }\end{array}$ & $\begin{array}{l}\text { Performance is } \\
\text { continuously tracked and } \\
\text { communicated, both } \\
\text { formally and informally, to } \\
\text { all staff using a range of } \\
\text { visual management tools }\end{array}$ \\
\hline $\begin{array}{l}\text { Targets }- \text { "How } \\
\text { Tough are } \\
\text { Targets?" }\end{array}$ & $\begin{array}{l}\text { Goals are either too } \\
\text { easy or impossible to } \\
\text { achieve; managers } \\
\text { low-ball estimate to } \\
\text { ensure easy goals }\end{array}$ & $\begin{array}{l}\text { In most areas, top } \\
\text { management pushes } \\
\text { for aggressive goals } \\
\text { based on solid } \\
\text { economic rationale. } \\
\text { There are a few } \\
\text { "sacred cows" not } \\
\text { held to the same } \\
\text { rigorous standard }\end{array}$ & $\begin{array}{l}\text { Goals are genuinely } \\
\text { demanding for all divisions. } \\
\text { They are grounded in solid } \\
\text { economic rationale }\end{array}$ \\
\hline $\begin{array}{l}\text { Incentives - } \\
\text { "Promoting high } \\
\text { Performers" }\end{array}$ & $\begin{array}{l}\text { People are promoted } \\
\text { primarily upon the } \\
\text { basis of tenure }\end{array}$ & $\begin{array}{l}\text { People are promoted } \\
\text { upon the basis of } \\
\text { performance }\end{array}$ & $\begin{array}{l}\text { We actively identify, } \\
\text { develop, and promote our } \\
\text { top performers }\end{array}$ \\
\hline
\end{tabular}

Appendix I: Interview scoring guide for management practices 